\title{
Conceptual Metaphors and Proverbs as Interactive Communicative Strategies in a XVII-century Ballad
}

\author{
Daniele Borgogni \\ Department of Humanistic Studies, University of Turin, Turin, 10124, Italy \\ daniele.borgogni@unito.it
}

\begin{abstract}
The article analyzes the presence of Conceptual Metaphors (CMs) in a XVII-century ballad in their interaction with popular proverbs as supplementary symbolizing patterns. The article will try to show the complexity of the mental processing involved in a special case of love disputation, in which CMs are made to interact with proverbs in order to produce implicatures. The use of CMs in the text and their interplay with proverbs and popular wisdom produce some unpredictable perlocutionary effects, which are not only significant indicators of the speakers' ideology and point of view, but also trigger communicative effects and a "proliferation of meanings" which confirm, or disrupt, certain socially 'inherited' conceptual structures both reflecting and shaping the thought patterns of a community.
\end{abstract}

\section{Indexing terms/Keywords}

Conceptual Metaphor, Proverb, Stylistics, Pragmatics, Ideology, Point of view, Implicature

\section{Academic Discipline And Sub-Disciplines}

Language and Linguistics

\section{SUBJECT CLASSIFICATION}

CLASS P - LANGUAGE AND LITERATURE; Subclass P; P301-301.5 Style. Composition. Rhetoric Library of Congress Classification

\section{TYPE (METHOD/APPROACH)}

Linguistic analysis

\section{AIMS AND METHODOLOGY}

In this article I would like to discuss the presence and use of Conceptual Metaphors (CMs) in a popular XVIIcentury ballad, The Youngmans careless Wooing, And the Witty Maids Replication (1680? $)^{1}$. In particular, due to the peculiar features of that text, especially its heavy reliance on proverbs, I will try to analyze the relationship between CMs and proverbs, and the way the communicative effects of their deployment convey (or question) certain socially 'inherited' conceptual structures both reflecting and shaping the thought patterns of the community.

Since the ground-breaking work of Ortony [37], Lakoff \& Johnson [32], and Lakoff \& Turner [33], Conceptual Metaphor Theory (CMT) has been the 'dominant' research paradigm in metaphor analysis ${ }^{2}$ as a pervasive element in thought and communication (Gibbs [19]; Kövecses [29] and [30]; Knowles \& Moon [28], Douthwaite [10]), and the analysis of CMs is an important clue to the way people mentally construct abstract domains.

If $\mathrm{CM}$ is a cognitive phenomenon by means of which an abstract concept is made more readily comprehensible thanks to the mappings which are transferred, usually from a concrete source domain onto an abstract target domain (see Lakoff \& Turner [33]: 63-4), analyzing the interplay between CMs and proverbs helps "reveal not just mental processes but also something of our culture" (Eubanks [12]: 421), which, in its turn, is a relevant indicator of the speaker's ideology and point of view.

The theoretical background to this study is, thus, CMT, but it is necessary to discuss in more detail some methodological aspects which are particularly important for the type of analysis I would like to propose.

\section{1}

As Fludernik ([17]: 160) reminds, the terminological change brought about by CMT is also a way to stress that "the ground (or, rhetorically speaking, the tertium comparationis) was not a static, essentialist pool of attributes shared by source and target but a semiotic interpretative construction generated by the very process of metaphoric transfer". CMT is, thus, particularly helpful for identifying underlying meanings, although one must be

\footnotetext{
${ }^{1}$ The text, licensed by Richard Pocock and printed for Philip Brooksby at the Golden Ball in Pye-Corner probably in 1680, can be found in the Pepys Library at Magdalene College, Cambridge (III, 130). A shortened version is included in the Additional notes to Ebsworth ([11]: 869).

${ }^{2}$ For an overview of CMT see Goatly [21], Grady, Oakley, \& Coulson [22], Knowles \& Moon [28], Gibbs [20], Kövecses [29], Lakoff [31]. See also Fauconnier \& Turner [14]; Charteris-Black [3], Deignan [6], Gentner \& Bowdle [18].
} 
wary of overgeneralizing on limited linguistic evidence. After all, as recent studies have demonstrated, identifying the CMs and their realizations in a text is only the first stage in interpretation. Even the simplest sentences are rife with a multiplicity of symbolizing patterns (see Douthwaite [7]: 205-66) and can perform a variety of communicative functions producing different levels of meaning.

Douthwaite [10] convincingly argued in favor of Sperber \& Wilson's idea that metaphors are analyzed as any indirect linguistic expression and that Linguistic Metaphors (LMs) must be understood by deploying an inferential process which cannot be limited to the mere identification of CMs. On the other hand, Kintsch ([27]: 129) maintained that "the simplest metaphors are processed in the same way as literal statements, while more complex metaphors require analogical reasoning". This means that metaphorical expressions are inherently intertwined with other linguistic mechanisms which provide additional non-literal meanings and conversational implicatures. It is therefore necessary to have a "mixed approach" which takes into account the mental processing of stylistic and pragmatic elements such as the ones highlighted by the cooperative principle (Grice [23]) or Relevance Theory (see Sperber \& Wilson [40], Goatly [21]; Vega Moreno [44], Tendahl \& Gibbs [41]), but also the other analytical frameworks employed in text analysis, if this allows a more in-depth and fulfilling appreciation of the text under scrutiny.

CMs perform various functions related to communication: as Gibbs ([19]: 124-5) demonstrated, apart from helping comprehension, they may "provide a way of expressing ideas that would be extremely difficult to convey using literal language" (the inexpressibility hypothesis; see also Gwyn [24]); they produce compact and vivid textual clots presenting rich and suggestive messages in a concise formulation; they perform "affective work" they are particularly suitable to persuasion ${ }^{4}$. Thus, the interpretation of a text cannot be limited to singling out the individual CMs and LMs, but must necessarily rely on pragmatic inferencing and stylistic analysis to account for the mechanisms that are activated by the addressee in order to understand the message in all its aspects.

\section{2}

Various levels of CMs have been identified (see Kövecses [30]: 95), from primary metaphors (representing a high level of generalization) to complex metaphors (representing the lowest level of generalization), which means that a metaphoric linguistic expression may actually be made up of a complex metaphor. More than this, metaphors may be "blended": according to Turner ([43]: 10) "conceptual blending is the mental operation of combining two mental packets of meaning ... to create a third mental packet of meaning that has new, emergent meaning", and Fludernik too ([16: 926) stressed that "Blending consists in fusing two scenarios together and thus creating new meaning effects" and blending theory "aims at combining metaphor and narrative under one cognitive umbrella". Blending theory ${ }^{6}$ in its original formulation maintained that, in processing language, the mind creates four mental spaces: the combination of the pertinent features of the target, the source and world knowledge produce a "blended" space that creates the interpretation of the specific linguistic expression being processed (see Grady, Oakley, \& Coulson [22]; Fauconnier \& Turner [14]). Blending, in other words, refers to a conceptual superimposition, a functional interaction between two "mental spaces" which produce new meanings by provoking a sort of mental change of perspective. It thus entails the capacity to use linguistic symbols in new combinations in order to produce new meanings (for this reason many speak of Conceptual Integration Theory).

In addition to this, LMs may provide more than two input spaces because they may be a composite of several CMs, or "multiple blends" as Fauconnier \& Turner ([14]: 279) define them: "there are two main ways in which networks can be multiple blends: either several inputs are projected in parallel, or they are projected successively into intermediate blends, which themselves serve as further inputs to further blends". More specifically, Fludernik [15]: 10) has pointed out that a metaphor may be a "semantically enriched construct" creating "new meanings not contained in either the source or target domains". This "proliferations of meaning" (Fludernik [15]: 11) has a direct effect on the structure of the analogies that can be made between source and target domains, creating numerous possible connections between the two domains, so that the same message can be legitimately read in very different ways (see the convincing example provided by Fludernik [15]: 10-11). Source and target domains, in

\footnotetext{
${ }^{3}$ The speaker's intention has a direct bearing on the deliberate pragmatic patterning on the text and its triggering of emotional reactions (such as alignment-distancing, positive-negative evaluation, emphasis-de-emphasis), because "When the topic of talk is uncomfortable for speakers in some way, metaphor helps to distance and deemphasize" (Cameron [2]: 203).

${ }^{4}$ For example, Charteris-Black ([3]: 7) states that "metaphor represents a novel way of viewing the world that offers some fresh insight". This of course implies a distinction between conventional metaphors and creative metaphors, the former being considered as relatively automatic and unconscious units having a conventional meaning-the 'literal' or 'surface' meaning of the expression as Goatly ([21]: 35) claims-or producing conventional implicatures-in Gricean terms-; the latter requiring greater processing effort because they entail a process of pragmatic inferencing (see Goatly [21]: 137-45). On the topic see Lakoff \& Turner [33]; Kövecses [30]; Deignan [6]; Knowles \& Moon [28].

${ }^{5}$ A classic example is the complex metaphor ARGUMENT IS A BUILDING, made up of two primary metaphors LOGICAL STRUCTURE IS PHYSICAL STRUCTURE and PERSISTING IS REMAINING ERECT.

${ }^{6}$ For a survey of critical discussion on CMT and blending theory in particular, see Eubanks [12]; Coulson \& Oakley [4]; McGlone [35]; Charteris-Black [3]; Deignan [6]; Crisp [5]; Tendahl \& Gibbs [41] and the special issue of Language and Literature [34]).
} 


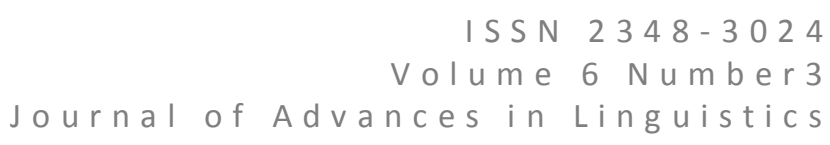

other words, can also be seen as input spaces which allow the blend to produce new meanings.

\section{3}

Lakoff \& Johnson [32]) already pointed out that CMs are necessarily partial: on the one side, CMs highlight one or more specific aspects of a phenomenon; on the other side, a given abstract concept may be conveyed by more than one CM (in terms of blending theory this means that there are more than two input spaces). Not all of the source domain features are mapped onto the target domain, but only those which are deemed pertinent to underscore certain aspects of the target $\mathrm{CM}$, hiding others. As a consequence, CMs are not only dependent on contextual variables (such as type of speech event or its $\mathrm{goal}^{7}$ ), but inherently ideological, since they reveal the speaker's point of view ${ }^{8}$ (see Douthwaite [8], [9] and [10]; Charteris-Black [3]). As I will try to demonstrate, the interplay of CMs in the text conveys a specific world view and is aimed at achieving a specific goal. The different worldviews of the two protagonists are conveyed by their different use of metaphor, revealing not only a deliberate and carefully calculated strategy in order to persuade the interlocutor, but also reflecting their contrasting individual interests.

\section{4}

If abstract subjects are generally talked about using metaphor, as linguistic evidence demonstrate, love has certainly been one of the most productive from this point of view. In this sense, The Youngmans careless Wooing belongs to a well-established genre, being basically a love skirmish between a young man and a girl. However, it stands out in that it features a conspicuous use of proverbs, pseudo-proverbs, "polluted" proverbs or refrains from a ballad or a dance song, maxims, sayings and jokes, with non sequiturs as part of the mockery. It thus displays a gamut of rhetorical strategies, including "illicit" emotive arguments and ad hominem attacks, not to mention humor and word play.

In fact, this use of proverbs is not unique, and can obvious be deployed for ironical purposes: Howell [25], for example, includes in his collection of proverbs, a letter composed of French, Italian, and Spanish proverbs. Nevertheless, this ballad presents a highly original use of proverbs which is particularly interesting from the vantage point of cognitive linguistics. The proverbial lore should reflect popular wisdom and general, commonly accepted opinions, and as such are consensus-assuming forms, the expression of the established truths of a given society (see Toolan [42]: 64-65).

But proverbs are also pervasive in thought and communication, and they have cognitive bearings, in that they help explain, reinforce or enrich the meaning and implicatures of abstract concepts, acting as a sort of bridge from two domains. This has particularly interesting consequences in those cases in which proverbs interact with metaphors: not only proverbs are often used as LMs, helping create a "blended" space where the features to be interpreted in the specific linguistic expression are produced; as Kövecses ([30]: 45) demonstrated, a metaphor "can give us a generic-level interpretation of a specific-level proverb and then allows us to apply the generic interpretation to a specific case that has the appropriate underlying generic structure".

In The Youngmans careless Wooing, the ballad form is not only a speech event consisting of a schematic exchange of views and arguments between the two speakers, since its heavy reliance on proverbs is much more than a simple manifestation of traditional opinions. The various utterances are often a blend of CMs, more or less successfully mixed with proverbs and popular wisdom, producing several metaphorical strands and thus revealing a crucial ideological role in the dialectic of the text. Proverbs, in other words, do not simply provide an "embellishment" to make the argument more convincing, but open the text to other implicatures. This means that proverbial expressions such as the ones that feature so prominently in The Youngmans careless Wooing provide supplementary symbolizing patterns and their interplay with CM in communicative use may yield interesting results to work out all the complexity of the text.

On the basis of these introductory remarks, the article will try to demonstrate the complexity of the mental processing involved in communication, the role of metaphor in the process and its interplay with proverbs and popular wisdom, which in turn can produce some unpredictable perlocutionary effects.

\section{DISCUSSION}

As the title states, the ballad should be sung to the tune of another famous ballad, The Lovers' Battle usually known as Mars and Venus ${ }^{2}$, centered on the usual verbal combat between the two gods and ending with the shameful "defeat" of Mars. As a co-text, this apparently neutral piece of information already triggers expectations and guides the reading process. This function is further reinforced by the external narratorial comment that opens

\footnotetext{
${ }^{7}$ As Lakoff \& Johnson [32] argued, the CM ARGUMENT IS WAR is typical in informal argumentation, while the CMs AN ARGUMENT IS A JOURNEY or AN ARGUMENT IS A BUILDING are more commonly found in more formal argumentative settings. See also Cameron [2] for a discussion of how metaphor density is affected by genre and topic.

${ }^{8}$ As Eubanks [12] convincingly argued, the selection of a certain CM does not necessarily mirror an individual's, but can be the expression of a culture, a given social class, even a gender.

${ }_{9}$ The ballad is included in Ebsworth ([11]: 707-708). For further information, see also the English Broadside Ballad Archive, University of California at Santa Barbara, Department of English.
}

$1030 \mid \mathrm{P}$ a g e

April 2016 council for Innovative Research w w w. ci r world.com 


\section{ISSN $2348-3024$

the text itself ${ }^{10}$ and frames the disputation between the young man and the maid:

(I)

Down in an Arbour devoted to Venus,

unseen I heard, two fond Lovers contend;

Noting how Cupid from business can wean us

and yet their Love, come to an unhappy end

The blinded Boy no victory wins,

As you shall hear he now begins.

However, this section is far from being a mere introduction to the text: the passing mention of the business from which Cupid usually wean people and the fact that in this case the blinded boy no victory wins is an important, though hidden, clue to one of the main ideological thrusts of the text. In other words, the text immediately, albeit in a subtle way, establishes a double level which must be answered with a double, layered reading, thus confirming the theoretical truism that any communicative event can only be interpreted in the light of shared knowledge of text and context.

(II)

I prethee Sweetheart grant me my desire,

for I am thrown as the old Proverb goes,

Out of the Frying-pan into the Fire:

and there is none doth pitty my woes,

Then hang or drown'd himself my muse

For there is not a T----- to choose.

The young man's argumentation goes from crudeness to cynicism: his initial, explicit request (grant my desire, II) is motivated by the negative situation he is going through, described by a well-known proverbial expression (to fall from the pan into the fire) which, according to the metaphor identification procedure designed by the Pragglejaz group [39] performs the function of Linguistic Metaphor. Even if its use seems surprising, there is not enough context and co-text to understand its illocutionary and perlocutionary effects (after all, the young man might be alluding to the classic CM LOVE IS FIRE). The last two lines of (II), however, are even more perplexing in a love disputation and, if on the one hand they reinforce the impression of a young man having real hardship, on the other the use of those two proverbial expressions is unexpected and costly in a relevance theoretic perspective, especially the colloquial term turd, duly foregrounded by the use of euphemistic hyphens.

(III)

Most Maids are false tho' some seem holyer

yet I believe they are all of one mind,

Like unto like, quoth the De'el to the Collier:

and they'l prove true when the Devil is blind,

Let no Man yield to their desire

For the burn'd Child doth dread the fire.

(III) continues and radicalizes the attack on women, with an opening relational process (stressing the difference between being and seeming) reinforced by another one, and a proverb (alluding to the collier who delivered coal and therefore looked as black as the Devil), which rely on the complex CM WOMEN ARE STANDARDIZED OBJECTS, with a further negative association of women to the Devil. The warning that closes (III) adds to it, albeit in a more indirect way: the proverb has not only a "literal", descriptive meaning, but plays on the slang meaning of burned as "infected with venereal disease" (Partridge [38]: 708). The classic source domain schema of movement and direction used by the young man (thrown ... out of, into the Fire, yield to) and the straightforward CM LOVE IS FIRE, are then used with a communicative goal that is almost the opposite of what the reader would expect.

\footnotetext{
${ }^{10}$ In the original text, proverbial expressions are written in a different font. In my transcription I underlined them to give a similar effect. I also numbered each stanza for easy reference.
}

1031 | P a g e

April 2016 council for Innovative Research

w w w. cir world. co m 


\section{ISSN $2348-3024$

(IV)

Tell me not my Love, as white as the Dove is

for you would say so if you saw her within

Shitten come shites the beginning of Love is,

and for her favour I care not a pin,

No love of mine, she ever shall be,

\section{Sirreverence of her Company.}

Even more shocking is (IV), dominated by the CM LOVE IS EXCREMENT: the word love itself is repeated three times, as if to avoid any possible doubt that it is the thing predicated of by the text, while proverbs perform the role of LMs: the first one (which had also been adapted to a popular song according to Pepys' Diary entry on Wednesday 17 April, 1661) significantly is a relational process foregrounding the vulgar expression; the last line of the stanza, with its foregrounded excrement euphemistically alluded to by the proverbial exclamation sirreverence (see Partridge [38]: 4830), confirms the negative nature of the maid's company. It does not come as a surprise that for the maid's favour the young man does not care a pin, meaning that he lacks any interest in her kindness but also that he is not willing to contaminate his pin (i.e. penis) with her favour (i.e. vagina). The proverb which closed (I), therefore, was not an exception, but fully inserted in a series of LMs contributing to the overall negative, vulgar characterization of love.

\section{(V)}

I will no more in love by her hands shake

let her go seek one that fits for her mind,

You know what's good for a Sow as a Pancake:

and under such Dirt, l'le ne're be confin'd

And he that hopes her Love to win,

Resolves to run through thick and thin.

(V) proposes an extremely elaborate interplay of complex CMs which, despite their variety, all contribute to dismissing sex and love: the first sentence has a perfectly acceptable literal meaning, presenting love in its tender, thrilling aspect. The verb shake, however, has an obvious sexual overtone ("To coït" and, as a reflexive, "to masturbate"; see Partridge [38]: 4688), which introduces the CM HUMANS ARE OBJECTS (confirmed by the material process fit) and what is perhaps the most shocking CM in the text: the proverb alluded to is "A turd's as good for a Sow as a Pancake", usually utilized to say that good things are not for fools, but here it is presented in a different guise, in order to evoke once again the vulgar term in what could be considered a case of foregrounding through ellipsis. Moreover, the term pancake is used to allude to "the female pudendum" (FarmerHenley [13]: 133) and is further specified in the following line as being dirt and a place of confinement: the CM HUMANS ARE OBJECTS, in other words, is further specified in a more complex and specific CM, THE FEMALE BODY IS A DIRTY PRISON. The final lines of (IV) revive the classic CM LOVE IS A JOURNEY, which, however, acquires other resonances: the idea evoked by the proverb (to run through thick and thin) is not so much that love spurs an individual to go through any obstacle heedless of the difficulties, but that love itself is that obstacle.

(VI)

Tho' her disdainfulness my heart hath cloven

yet am I of so gallant a mind

l'le ne'r creep in her Arse to bake in her oven.

for 'tis an old Proverb, Cat after kind,

And this I'le say until I dye,

Farewel \& be hang'd, that's I wis good buy.

The concluding section VI confirms the main CM HUMANS ARE OBJECTS (the lover's heart is cloven, the maid's arse is a place to creep in, her sexual organs are an oven, see Farmer-Henley [13]: 116), even though the young man recurs to MEN ARE ANIMALS to speak about himself and his natural tendency (Cat after kind) to arrive at sexual fulfilment (the usual pun of the verb die). The final proverb deserves a closer scrutiny: Howell ([25]: 11) reports it as Farewell and be hang'd that is twise God be with you, but the common mild oath Farewell and be hang'd was often combined and completed with other sententious expressions, such as friends must part, goodman cowe, or that's twice goodbwy (see Apperson, Manser, \& Curtis [1]: 192). As to the archaic form Iwis (meaning "certainly, indeed"), it was also mistakenly written as I wis, and often confused with the verb to wit. The young man's version is thus deeply ambiguous: it could mean "That's what I wish to you, goodbye", "That's certainly a goodbye", but also "That's I know is a good buy", a hermeneutic hypothesis which provides an 


\section{ISSN $2348-3024$

interesting clue whose relevance will appear at the end of the text.

The first part of the ballad, then, seems curiously at odds with the title, in that it is difficult to consider the young man's words as an example of wooing: love is conceptualized through various source domains as a radically negative phenomenon, women as standardized, devilish objects, and female sexuality as filth and excrement. The maid's wit will be apparent not so much in her rebuttal of these apparently cynical and bitter conceptualization, but in her hermeneutic capacity of exposing the real motivations behind this "wooing".

The Witty MAIDS Answer.

(VII)

The silly Maid drown'd in Tears of vexation,

sending to him whom she lov'd best of all;

Such a sad sonnet so pester'd with passion

tearing her hair to the ground she did fall,

But rising up undauntedly

she unto him made this reply.

Another external narratorial comment introduces the maid's answer. The editor of the Roxburghe Ballads (see Ebsworth [11]: 869) describes this part as follows: "After three more stanzas he gets 'The "Witty Maid's Answer.' At first she was "drown'd in tears of vexation," tearing her hair and falling to the ground, but she soon makes reply in his own fashion." In fact, her reply will not be made in his own fashion at all; more importantly, the external point of view provides a fundamental perspective on the maid, by explicitly stating that her dramatic reaction (drown'd in Tears of vexation, tearing her hair to the ground she did fall) is the one of a silly girl pester'd with passion. The real, witty answer is the one that comes from an undaunted woman who rises up. By juxtaposing so openly the classic CMs DOWN IS BAD vs. UP IS GOOD, the external voice makes clear that the young woman will not comply with the young man's rhetoric and attitude, even less his cynical and vulgar approach conveyed through disturbing CMs. It is as if the text wanted to assert that if the maid had been a silly girl, she would have swallowed the bait and behaved in that irrational way induced by passion pestering; on the contrary, she is not impressed by the young man's "wooing" and progressively deconstructs it exposing its true rationale.

(VIII)

If I should grant unto thee thy desire

without obtaining my Mother good will

Then I'm sure all the Fats in the Fire:

I know what I think, and think I will still,

my Muse and yours are paltry Elves

They may go hang and drown themselves.

(IX)

Thou may'st go follow thy sweetheart to Norwich

she is a Lass that's fit for your Tooth,

\section{A Sluts good enough to make Slovens Porridge}

and that was the reason yea left me forsooth;

But this I say, and will do still,

'Tis a good Jack makes a good Jill.

The maid starts her reply in (VIII) along the lines of the young man's (II): once again the fire is not used to allude to the CM LOVE IS FIRE but rather to DESIRE IS DANGEROUS, a conceptualization which is confirmed by the description of human attitudes as paltry Elves which should proverbially hang and drown themselves.

From this moment on, however, the girl follows a different path, revealing new important elements: the young man's falling out of the pan into the fire was the consequence of his disastrous wooing of another sweetheart, now run away to Norwich, who was probably of his same mould and more adaptable to his cast of mind: she was fit for his tooth (WOMEN ARE FOOD or MEN ARE PREDATORS) and if he has fully proved a sloven (at least in his manners), she is a slut (here used as a derogatory term but with no sexual overtones). Similarly, a good wife is such because of the good husband she has, two people mutually helping each other. The two proverbs the maid uses in (IX) are then both aimed at stressing that LOVE IS AFFINITY, based on partners' equality. 


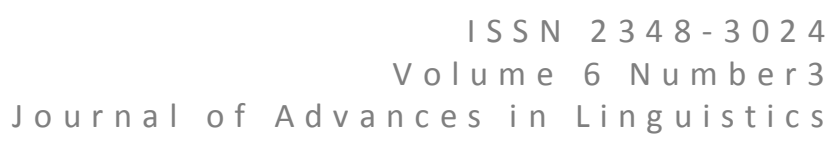

(X)

I must confess that I loved thee well one day,

but e're that thou findst me do so again,

Thou shalt come kiss me where I sat on Sunday;

We foolish Maids put to much trust in Men,

For when we think we are in our Heaven,

You leave us all at sixes and seavens.

In $(X)$ the proverbial expression "Thou shalt come kiss me where I sat on Sunday", the only vulgar euphemism used by the maid, underscores her decision not to return the young man's proposal, but the following lines are all based on rather traditional CMs: HUMANS ARE CONTAINERS (We ... put too much trust in Men), BLISS IS A PLACE (we think we are in our Heaven), and LOVE IS A GAME (You leave us all at sixes and seavens). As Nares ([36]: 729-30) explains, the latter metaphor comes from backgammon or other table games: to leave single people exposed to the throws of six and seven, is to leave them negligently and under the greatest hazard, since there are more chances for throwing those numbers than any other.

(XI)

Thou only seekest to know where my stock is

But stay by my troth, some are wiser than som

Near is my Petticoat, nearer my Smock is,

and thy Entertainment shall be like Jack Drum

For when my Portion thou hast got,

'Tis need that makes the old Wife trot.

(XI) gives an unexpected turn to the confrontation: the maid basically relies on MEN ARE PREDATORS (Thou only seekest to know where my stock is, when my Portion thou hast got), but interestingly the CM and the proverbs (with a significant and unique accumulation, four in six lines) are not just used in a metaphorical way, but retain their literal meaning. Such terms as stock and Portion are usual euphemisms alluding to female sexual organs, but they also signify the property which is given to a woman on her marriage (see Partridge [38]: 4407). The same is true for the proverb Near is my petticoat but nearer is my smock, which undoubtedly means "Some friends are nearer to me than others" as Kelly ([26]: 112) argues, but also keeps its literal meaning denoting the two basic women's clothes.

The allusion to Jack Drum's Entertainment was a proverbial expression for a rough reception, but once again its intertextual dimension triggers a "proliferation of meaning" which is worth considering: the phrase comes from John Marston's homonymous drama (1601) which presents a love triangle in which a rejected suitor smears poison on a girl's face, who is about to commit suicide until she is rescued by her true love, her face is miraculously restored and the two lovers finally get married. The allusion not only allows the maid to dismiss the young man, but also underscores the physical consequences that her yielding might have: she would lose her honor, but more importantly, her livelihood. This is confirmed by the last line, whose proverb 'Tis need that makes the old Wife trot, confirms the simultaneous presence of the symbolic and literal planes, implying that a concrete source domain is not only projected onto an abstract target domain to explain and make it more comprehensible, but also maintains its concrete, real meaning. In other words, the maid identifies her virtue with her property: her virginity is strictly tied to economic aspects, and her vision of love could be summarized by the CM LOVE IS AN ECONOMIC EXCHANGE.

(XII)

And thus to conclude upon our conferring,

most Men are as false, very few Men are true

They are neither Fish, Flesh, nor yet good red herring

we must speak truth, give the Devil his dew:

And this shall be my last reply

Go walk up out Knave what care I.

The definitive rebuttal of the young man's "wooing" in (XII) is then carefully built and comes as the inevitable consequence of the denunciation of the falsity of men. The young man had said very early in his argumentation that Most Maids are false (III), presenting this claim as a general truth but without any evidence. On the contrary, the maid's similar accusation comes on top of a long analysis of the young man's real motivation, and the fact that his love hides something else: the obsessive presence of excrements and anal intercourse is a telling indication 


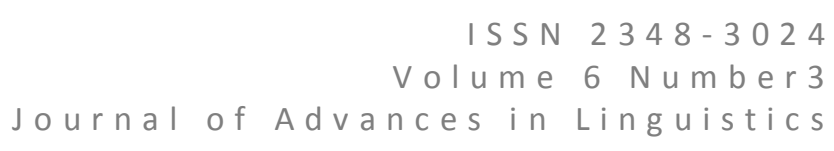

of the young man's perspective on love as a vulgar, essentially physical act, but more importantly, it is a sort of smokescreen hiding the real motivation and the real nature of his "desire", that is the economic element exposed by the maid's answer.

The concluding CMs are the logical outcome of this: reversing the young man's accusation, the maid recurs to the proverb neither fish, flesh, fowl, nor good red herring not to imply that men are hesitant but to suggest that MEN ARE ANIMALS, and if the young man had put forward the commonplace denunciation of the women's devilish nature, the maid rightly points out that in fact MEN ARE DEVILS: by exposing the real motivation of the young man, she really speaks truth and gives the Devil his dew by repelling him for good.

\section{CONCLUSION}

In this article I tried to demonstrate how the analysis of the relationship between CMs and proverbs produces interesting communicative effects which, in their turn, become carriers of certain socially 'inherited' conceptual structures (the traditional sexual roles) but can also hide deeper motivations and more covert implicatures. Two basic types of "argumentative genre" which characterize the text are enriched by the presence of many proverbs which should render the argumentation more cogent and convincing but that in fact produce unexpected perlocutionary effects.

Far from performing the role of conventional or dead metaphorical expressions, whose processing is relatively automatic and unconscious as matter-of-fact truths, proverbs and saying can thus also be deployed as LMs, requiring a far more refined and time consuming processing effort for their comprehension because they convey other implicatures. It is also of particular interest to study the tensions and contradictions that emerge once we start mapping metaphors, not only because the choice of a source domain highlights only certain aspects of a concept, thus presenting the target domain from a very precise ideological point of view, but also because the "philosophy" conveyed by the proverb, its use as a specific linguistic metaphor and its blending are sometimes at odds with $\mathrm{CM}$ they should produce.

Interestingly enough, the young man's wooing contains in most cases creative, unexpected though shocking CMs, whose purpose is, however, to obtain his sexual and economic desire; the maid's CMs are less creative, but more effective in deconstructing the young man's conventional wisdom and in exposing the young man's specious arguments.

\section{REFERENCES}

[1] Apperson, G. L., Manser, M.H., \& Curtis, S.J. 2006. Dictionary of Proverbs. Ware: Wordsworth Editions Ltd.

[2] Cameron, L.J. 2008. Metaphor and talk. In R.W. Gibbs (Ed.), The Cambridge Handbook of Metaphor and Thought (pp. 197-211). Cambridge: Cambridge University Press.

[3] Charteris-Black, J. 2004. Corpus Approaches to Critical Metaphor Analysis. Houndmills: Palgrave.

[4] Coulson, S., \& Oakley, T. 2000. Blending Basics, Cognitive Linguistics, 11.3-4, 175-96.

[5] Crisp, P. 2008. Between Extended Metaphor and Allegory: Is Blending Enough? Language and Literature, 17.4, 291-308.

[6] Deignan, A.A. 2005. Metaphor and Corpus Linguistics. Amsterdam: John Benjamins.

[7] Douthwaite, J. 2000. Towards a Linguistic Theory of Foregrounding. Alessandria: Edizioni dell'Orso.

[8] Douthwaite, J. 2003. Pragmatic patterning as foregrounding: Albert Camus' L'Etranger. In I. Loi Corvetto (Ed.), II testo: meccanismi linguistici e strategie retoriche (pp. 101-120). Roma: Carocci.

[9] Douthwaite, J. 2009. Pragmatic Patterning in the Deployment of Conceptual Metaphor and Communication. Plurilinguismo, 16, 83-117.

[10] Douthwaite, J. 2011. Conceptual Metaphor and Communication. In M. Fludernik (Ed.), Beyond Cognitive Metaphor Theory: Perspectives on Literary Metaphor (pp. 137-157). London: Routledge.

[11] Ebsworth, J.W. (Ed.). 1897. The Roxburghe Ballads, Illustrating the Last Years of the Stuarts (vol. IX). Hertford: Stephen Austin \& Sons.

[12] Eubanks, P. 1999. The Story of Conceptual Metaphor: What Motivates Metaphoric Mappings? Poetics Today, 20.3, 419-42.

[13] Farmer, J.S., \& Henley, W.E. (Eds.). 1902. Slang and its Analogues, Past and Present (Vol. V). London: Printed for Subscribers only.

[14] Fauconnier, G., \& Turner, M. 2002. The Way We Think: Conceptual Blending and the Mind's Hidden Complexities. New York: Basic Books.

[15] Fludernik, M. 2010a. Naturalizing the unnatural: A view from blending theory. Journal of Literary Semantics, 39, 1-27. 
[16] Fludernik, M. 2010b. Narratology in the Twenty-First Century: The Cognitive Approach to Narrative. PMLA, 125.4, 924-930.

[17] Fludernik, M. 2015. Blending in Cartoons: The Production of Comedy. In L. Zunshine (Ed.), The Oxford Handbook of Cognitive Literary Studies (pp. 155.175). Oxford: Oxford University Press.

[18] Gentner, D., \& Bowdle, B.F. 2008. Metaphor and Structure-Mapping. In R.W. Gibbs (Ed.), The Cambridge Handbook of Metaphor and Thought (pp. 109-128). Cambridge: Cambridge University Press.

[19] Gibbs, R.W. 1994. The Poetics of Mind. Cambridge: Cambridge University Press.

[20] Gibbs, R.W. (Ed.). 2008. The Cambridge Handbook of Metaphor and Thought. Cambridge: Cambridge University Press.

[21] Goatly, A. 1997. The Language of Metaphors. London: Routledge.

[22] Grady, J.E., Oakley, T., \& Coulson, S. 1999. Blending and Metaphor. In R.W. Gibbs, \& G.J. Steen (Eds.), Metaphor in Cognitive Linguistics (pp. 102-24). Amsterdam: John Benjamins.

[23] Grice, P. 1989. Studies in the Way of Words. Cambridge, MA: Harvard University Press.

[24] Gwyn, R. 1999. 'Captain of my own ship': Metaphor and the discourse of chronic illness. In L.J. Cameron, \& G.D. Low (Eds.), Researching and Applying Metaphor (pp. 203-220). Cambridge: Cambridge University Press.

[25] Howell, J. 1659. ПАРОІМІОГРАФІА. Proverbs, or, Old Sayed Savves \& Adages. London: Printed by J. G..

[26] Kelly, W.K. 1859. Proverbs of All Nations, Compared, Explained, And Illustrated. London: W. Kent \& Co.

[27] Kintsch, W. 2008. How the Mind Computes the Meaning of Metaphor. In R.W. Gibbs (Ed.), The Cambridge Handbook of Metaphor and Thought (pp. 129-142). Cambridge: Cambridge University Press.

[28] Knowles, M., \& Moon, R. 2006. Introducing Metaphor. London: Routledge.

[29] Kövecses, Z. 2005. Metaphor in Culture. Universality and Variation. Cambridge: Cambridge University Press.

[30] Kövecses, Z. 2010. Metaphor. A Practical Introduction ( $2^{\text {nd }}$ Edition). Oxford: Oxford University Press.

[31] Lakoff, G. 2008. The neural theory of metaphor. In R.W. Gibbs (Ed.), The Cambridge Handbook of Metaphor and Thought (pp. 17-38). Cambridge: Cambridge University Press

[32] Lakoff, G., \& Johnson, M. 1980. Metaphors We Live By. Chicago: University of Chicago Press.

[33] Lakoff, G., \& Turner, M. 1989. More Than Cool Reason. Chicago: University of Chicago Press.

[34] Language and Literature, 15.1. 2006. Special issue on Blending.

[35] McGlone, M.S. 2001. Concepts as Metaphors. In S. Glucksberg (Ed.), Understanding Figurative Language: From Metaphors to Idioms (pp. 90-107). New York: Oxford University Press.

[36] Nares, R. 1825. A Glossary or Collection of Words, Phrases, Names, and Allusions to Customs, Proverbs, Stralsund: printed for Charles Loeffler.

[37] Ortony, A. (Ed.). 1979. Metaphor and Thought. Cambridge: Cambridge University Press.

[38] Partridge, E. 1973. The Routledge Dictionary of Historical Slang (abridged by Jacqueline Simpson. London: Routledge.

[39] Pragglejaz Group. 2007 MIP: A method for identifying metaphorically used words in discourse. Metaphor and Symbol, 22.1, 1-39.

[40] Sperber, D., \& Wilson, D. 1995. Relevance. Communication and Cognition, (2 ${ }^{\text {nd }}$ ed.). Oxford: Blackwell.

[41] Tendahl, M., \& Gibbs, R.W. 2008. Complementary Perspectives on Metaphor: Cognitive Linguistics and Relevance Theory. Journal of Pragmatics, 40, 1823-64.

[42] Toolan, M. 1998. Language in Literature. An Introduction to Stylistics, London: Arnold.

[43] Turner, M. 2002. The Cognitive Study of Art, Language and Literature. Poetics Today, 23.1, 9-20.

[44] Vega Moreno, R.E. 2007. Creativity and Convention. The pragmatics of everyday figurative speech. Amsterdam: John Benjamins. 


\section{Author's biography with Photo}

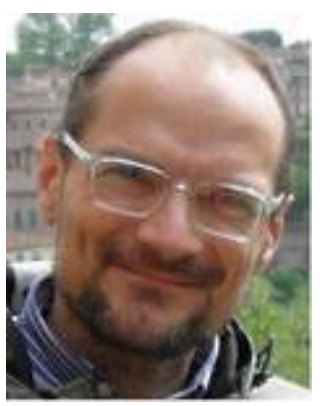

Daniele Borgogni is research fellow in English and Translation Studies at the University of Turin, where he has been teaching English and Translation Studies since 2000. He specializes in translation theory and practice, stylistics and cognitive linguistics, with a particular interest in for the study and analysis of English texts of the XVII century and the multisemiotic textual forms of European emblematics. He also contributed to several encyclopaedic works on English literature. $\mathrm{He}$ is the author of a monograph on "Paradise Regained" (1998), co-editor of a collection of essays on religious and literary discourse in early modern France and England (2005), editor of didactic manuals on translation for Italian students $(2007 ; 2010)$. He also published the first Italian critical edition (introduction, translation and notes) of John Milton's "Paradise Regained" (2007) and is the editor (introduction, translation and notes) of "Cymbeline", "1Henry VI", "2Henry VI" and "3Henry VI" for the new Italian edition of Shakespeare's complete works (2014- ). 